\title{
Efek Penggunaan Limbah Kue Pia Sebagai Pengganti Jagung Terhadap Performan Ayam Sentul
}

\author{
D. N. R. Hidayat ${ }^{1}$, M. Royani ${ }^{2 a}$ \\ ${ }^{I}$ Mahasiswa Program Studi Peternakan Fakultas Pertanian Universitas Garut \\ ${ }^{2}$ Dosen Program Studi Peternakan Fakultas Pertanian Universitas Garut \\ aemail : mega_royani@uniga.ac.id
}

\begin{abstract}
Abstrak
Penelitian ini bertujuan untuk mengatahui level optimal pemberian tepung limbah kue pia sebagai pengganti jagung terhadap performan ayam sentul. Penelitian ini dilaksanakan di di Desa Sirna Galih, Kecamatan Cigalontang, Kabupaten Tasikmalaya dari 29 Desember 2016 sampai 23 Februari 2017. Rancangan percobaan yang digunakan adalah rancangan acak lengkap (RAL) dengan 5 perlakuan dan 4 ulangan dan apabila menunjukkan hasil berbeda nyata akan dilanjutkan dengan Uji Jarak Berganda Duncan's (UJBD). Adapun perlakuan yang digunakan adalah R1 (tepung limbah kue pia 10\% dan jagung 50\%) R2 (tepung limbah kue pia 20\% dan jagung 40\%) R3 (tepung limbah kue pia 30\% dan jagung 30\%) R4 (tepung limbah kue pia 40\% dan jagung 20\%) R5 (tepung limbah kue pia 50\% dan jagung 10\%). Variabel yang diamati adalah konsumsi ransum, pertambahan bobot badan dan konversi ransum. Hasil penelitian menunjukkan bahwa perlakuan berpengaruh nyata $(\mathrm{P}<0,05)$ terhadap konsumsi ransum, pertambahan bobot badan dan konversi ransum. Berdasarkan hasil penelitian dapat disimpulkan bahwa penggunaan tepung limbah kue pia pada taraf 30\% (R3) menunjukkan performan ayam sentul yang paling optimal.
\end{abstract}

Kata kunci: Ayam Sentul, Performan, Tepung Limbah Kue Pia

\section{Effect Of Pia Cake Waste Addition As Corn Substitution On Performance Of Sentul Chicken}

\begin{abstract}
The reseach was aimed to find out the optimum level pia cake waste as corn subtitution on performance of sentul chicken. The research was conducted in Sirna Galih village, Cigalontang District, Tasikmalaya and held from 29 December 2016 to 23 February, 2017. The experimental design used was a complete randomized design (RAL) with 5 treatments and 4 replicates and if it showed a significantly different result it would be continued with Duncan's Multiple Range Test (DMRT). The treatment used is R1 (10\% pia cake waste and 50\% corn), R2 (20\% pia cake waste and $40 \%$ corn), R3 (30\% pia cake waste and $30 \%$ corn) $R 4$ (40\% cake pia waste and $20 \%$ corn), $R 5$ ( $50 \%$ pia cake waste and $10 \%$ corn). The variable measured were feed intake, body weight gain and feed conversion. The results showed that the treatment had significant effect $(P<0.05)$ on feed intake, body weight gain and feed conversion. Based on the result of the research can be concluded that the use of pia cake waste at level $30 \%$ (R3) shows the most optimal performance of sentul chicken.
\end{abstract}

\section{Keywords: Sentul chicken, Performance, Pia Cake Waste Cake}

\section{Pendahuluan}

Ayam sentul merupakan ayam kampung asli dari daerah Kabupaten Ciamis dan penelitian menunjukan bahwa ayam Sentul memiliki keunggulan dalam pertumbuhan bobot badan dan produksi telur sehingga memiliki potensi untuk dikembangkan dalam upaya meningkatkan pendapatan peternak (Sudrajat dan Isyanto, 2018). Perkembangan ayam sentul saat ini masih sangat rendah sehingga perlu adanya peningkatan performan ayam sentul agar menjadi salah satu ayam yang unggul dan menjadi salah satu komoditas ternak yang mampu memenuhi kebutuhan pasar.

Jagung kuning biasa digunakan untuk campuran ransum sebagai sumber energi dalam ransum ayam, karena bahan pakan 
tersebut mengandung energi metabolis tinggi, serat kasar rendah dan asam amino yang cukup untuk pertumbuhan ayam (Widjastuti, 2009). Kendalanya jagung kuning harganya masih terbilang mahal sehingga perlu dicari bahan alternatif yang kandungan gizinya mendekati jagung kuning dan harganya relatif lebih murah dan tidak bersaing dengan manusia. Menurut Wahyu (2004) jagung kuning mengandung Protein kasar 8,6\%, serat kasar $3,9 \%$, lemak kasar $2 \%$, energi metabolis 3370 $\mathrm{Kkal} / \mathrm{kg}$.

Bahan pakan alternatif yang dapat digunakan sebagai pengganti jagung dan tidak bersaing dengan kebutuhan manusia adalah tepung limbah kue pia kacang hijau. Hasil analisa proksimat Laboratorium Nutrisi Ternak Ruminansia dan Kimia Makanan Ternak Fakultas Peternakan UNPAD (2016), tepung limbah kue pia kacang hijau mengandung protein kasar 13,14\%, serat kasar $0,81 \%$, lemak kasar 9,84\%, karbohidrat 74,65\% Air $16,86 \%$ dan Abu 1,56\% serta Energi Bruto $3367 \mathrm{kkal} / \mathrm{kg}$. Dilihat dari nilai nutrisinya, tepung limbah kue pia termasuk kedalam bahan pakan sumber energi, sehingga dapat dijadikan sebagai pengganti jagung.

Berdasarkan uraian di atas, kelebihan tepung limbah kue pia jika dibandingkan dengan jagung adalah kandungan protein yang lebih tinggi serta serat kasar yang lebih rendah. Limbah kue pia memiliki kesamaan dengan limbah roti dalam bahan dasar pembuatannya yaitu tepung dan telur. Menurut hasil penelitian Alfi (2009) penggantian jagung dengan tepung roti afkir hingga taraf 30\% dapat menghasilkan karkas yang optimal pada ayam broiler. Penambahan limbah roti dalam ransum sampai $30 \%$ dapat direspon dengan baik terhadap efisiensi penggunaan ransum dan income over feed and chick cost ayam broiler (Widjastuti dan Sudjana, 2009). Penggunaan roti afkir sampai $30 \%$ dalam pakan jadi masih dapat dilakukan dengan tidak menimbulkan efek negatif pada performa burung puyuh, dan dapat memberikan keuntungan ekonomis lebih besar (Gaol et al, 2015)

\section{Materi dan Metoda}

Ternak percobaan yang digunakan pada penelitian adalah 100 ekor ayam sentul umur 3 minggu di pelihara sampai umur 11 minggu dengan tanpa adanya pemisahan jenis kelamin (straight run). Ayam sentul yang digunakan dalam penelitian didapat dari BPPTU Majalengka. Kandang yang digunakan adalah kandang batre dengan ukuran Panjang $\mathrm{x}$ Lebar x Tinggi adalah $100 \mathrm{~cm} \times 60 \mathrm{~cm}$ x 50 $\mathrm{cm}$ dan diisi 5 ekor Ayam Sentul untuk masing-masing batre. Setiap kandang diberi nomor sesuai dengan perlakuan dan ulangan.

Bahan pakan yang digunakan untuk menyusun ransum adalah tepung jagung, tepung limbah kue pia, dedak dan konsentrat ayam pedaging (CP 112) produksi Charoen Phokphand. Ransum disusun berdasar pada penelitian Indra et al., (2015) dengan kandungan protein $17,5 \%$ dan energi metebolis $2800 \mathrm{Kkal} / \mathrm{Kg}$. Limbah kue pia kacang hijau yang digunakan adalah kue pia yang sudah kadaluarsa dan ditarik dari pasaran kurang dari 1 minggu yang di tandai dengan mulai tumbuhnya bintik-bintik jamur di sekitar kue. Limbah kue pia kemudian dikeringkan dan dibuat tepung. Susunan ransum perlakuan yang digunakan dalam penelitian dapat dilihat pada Tabel 1.

Tabel 1. Komposisi Bahan Pakan Percobaan

\begin{tabular}{lccccc}
\hline \multirow{2}{*}{ Bahan Pakan } & \multicolumn{5}{c}{ Perlakuan } \\
\cline { 2 - 6 } & R1 & R2 & R3 & R4 & R5 \\
\hline Tepung Jagung & 50 & 40 & 30 & 20 & 10 \\
Tepung Kue Pia & 10 & 20 & 30 & 40 & 50 \\
Dedak & 9 & 8 & 5 & 5 & 5 \\
Konsentrat Pedaging & 29 & 29 & 28 & 27 & 27 \\
Minyak Kelapa & 1 & 1 & 2 & 3 & 3 \\
Tepung Tapioka & 1 & 2 & 5 & 5 & 5 \\
\hline Jumlah (\%) & 100 & 100 & 100 & 100 & 100 \\
\hline
\end{tabular}


Tabel 2. Kandungan Nutrisi Ransum Percobaan

\begin{tabular}{lccccc}
\hline \multirow{2}{*}{ Nutrisi Pakan } & \multicolumn{5}{c}{ Perlakuan } \\
\cline { 2 - 6 } & R1 & R2 & R3 & R4 & R5 \\
\hline Energi Metabolis & 2877 & 2830 & 2889 & 2884 & 2817 \\
Protein Kasar & 17,15 & 17,50 & 17,29 & 17,39 & 17,84 \\
Lemak Kasar & 5,99 & 6,46 & 7,68 & 9,24 & 9,83 \\
Serat Kasar & 5,08 & 4,86 & 4,33 & 4,11 & 3,99 \\
Ca & 0,89 & 0.89 & 0,87 & 0,83 & 0,83 \\
$\mathrm{P}$ & 0,42 & 0.41 & 0,38 & 0.36 & 0,35 \\
\hline
\end{tabular}

Kandungan nutrisi ransum percobaan yang digunakan dalam penelitian dapat dilihat pada Tabel 2.

Variabel yang diamati yaitu

1. Konsumsi ransum: Konsumsi ransum adalah rataan ransum yang dikonsumsi ayam per perlakuan selama penelitian yang di ukur dengan satuan gram,

2. Pertambahan bobot badan: Pertambahan bobot badan adalah rataan bobot badan setiap perlakuan selama penelitian yang diambil setiap minggu dan diukur dengan satuan gram

3. Konversi ransum: Konveri ransum adalah perbandingan antara jumlah ransum yang dikonsumsi selama penelitian dengan pertambahan bobot badan akhir.

adalah $\begin{gathered}\text { Metode penelitian yang digunakan } \\ \text { metode percobaan dengan }\end{gathered}$ menggunakan desain Rancangan Acak Lengkap (RAL) dengan menggunakan 5 perlakuan dan 4 kali ulangan. Perlakuan yang diberikan adalah $\mathrm{R} 1=$ tepung limbah kue pia
$10 \%$ dan jagung 50\%, R2 = tepung limbah kue pia $20 \%$ dan jagung $40 \%$, R3 = tepung limbah kue pia $30 \%$ dan jagung $30 \%, \mathrm{R} 4=$ tepung limbah kue pia $40 \%$ dan jagung $20 \%$ dan R5 = tepung limbah kue pia 50\% dan jagung 10\%

\section{Hasil dan Pembahasan}

Berdasarkan hasil penelitian diperoleh rataan nilai konsumsi pakan selama penelitian yang disajikan pada Tabel 3 .

\section{Pengaruh Perlakuan terhadap Konsumsi Ransum}

Berdasarkan hasil penelitian pada Tabel 3. dapat dilihat bahwa pemberian limbah kue pia memperlihatkan pengaruh yang nyata terhadap konsumsi ransum. Hasil Uji Jarak Berganda Duncan (UJBD) menunjukkan bahwa pada perlakuan R3 dn R4 nyata lebih rendah jika dibandingkan dengan perlakuan R2 dan R1, tetapi tidak berbeda nyata dengan R5.

Tabel 3. Hasil Uji Pengaruh Perlakuan terhadap Konsumsi Ransum, Pertambahan Bobot Badan dan Konversi Ransum Ayam Sentul

\begin{tabular}{cccc}
\hline \multirow{2}{*}{ Perlakuan } & \multicolumn{3}{c}{ Variabel Pengamatan } \\
\cline { 2 - 4 } & Konsumsi Ransum & PBB & Konversi Ransum \\
\hline R1 & $2940,45^{\mathrm{c}}$ & $1011,25^{\mathrm{c}}$ & $2,91^{\mathrm{a}}$ \\
R2 & $2788,95^{\mathrm{b}}$ & $934,20^{\mathrm{b}}$ & $2,99^{\mathrm{ab}}$ \\
R3 & $2672,20^{\mathrm{a}}$ & $923,20^{\mathrm{ab}}$ & $2,91^{\mathrm{a}}$ \\
R4 & $2683,85^{\mathrm{a}}$ & $887,30^{\mathrm{a}}$ & $3,02^{\mathrm{ab}}$ \\
R5 & $2739,15^{\mathrm{ab}}$ & $855,35^{\mathrm{a}}$ & $3,20^{\mathrm{b}}$ \\
\hline
\end{tabular}

Keterangan: Superskrip yang berbeda menunjukkan perbedaan yang nyata $(\mathrm{P}<0,05)$ 
Perbedaan konsumsi ransum ini diperkirakan karena dipengaruhi oleh kandungan energi dalam ransum perlakuan R3 dan R4 memiliki rata-rata kandungan energi lebih tinggi dibanding yang lain, yaitu 2889 $\mathrm{Kkal} / \mathrm{kg}$ dan $2884 \mathrm{Kkal} / \mathrm{kg}$. Sesuai dengan pendapat Kompiang et al., (2001) ayam kampung seperti unggas lainnya, ternyata dalam hal konsumsi ransum dibatasi oleh pemenuhan kebutuhan energi terlebih dahulu, setelah itu ayam kampung akan menentukan kebutuhan protein bila memungkinkan. Apabila kebutuhan energi ternak sudah tercukupi maka konsumsi akan sedikit dan sebaliknya (Rasyaf, 2002). Hal ini yang menyebabkan konsumsi ransum pada perlakuan R3 dan R4 lebih sedikit akibat kandungan energi ransum yang lebih tinggi.

Konsumsi ransum dibutuhkan ayam untuk memenuhi kebutuhan energi pokok hidup dan selebihnya akan digunakan untuk pertumbuhan. Menurut Indra et al (2015), kebutuhan energi untuk ayam sentul adalah $2871,15 \mathrm{Kkal}$. Sedangkan kandungan energi yang digunakan pada perlakuan R3 dan R4 adalah $2889 \mathrm{Kkal}$ dan $2884 \mathrm{Kkal}$, kandungan energi yang berlebih pada ransum perlakuan R3 dan R4 inilah yang menyebabkan konsumsi ransumnya lebih sedikit

\section{Pengaruh Perlakuan \\ Pertambahan Bobot Badan}

terhadap

Hasil rataan pada Tabel 3 . memperlihatkan bahwa rataan bobot badan yang paling tinggi adalah perlakuan R1 (1011,25 gram), diikuti berturut turut pada perlakuan R2 (931,35 gram), R3 (923,20 gram), dan R4 (887,30 gram), sedangkan rataan pertambahan bobot badan yang rendah ditunjukkan pada perlakuan R5 (855,80 gram). Hasil ini lebih besar jika dibandingkan dengan rataan pertmbahan bobot badan ayam kampung yang dipelihara dari umur 2 sampai minggu ke 12 dengan ransum bebas mmilih yaitu 858,03 gram (Kompiang, 2001). Setelah dilakukan Uji Jarak Berganda Duncan (UJBD) hasilnya menunjukkan bahwa pada perlakuan $\mathrm{R} 5$, R4 dan R3 tidak berbeda nyata, tetapi berbeda nyata dengan R2 dan R1.

Anggorodi (1994), menyatakan bahwa berat badan ayam akan ditentukan oleh jumlah konsumsi pakan dengan kandungan energi dan protein yang seimbang. Hasil dari penelitian ini, semakin tinggi pemberian limbah kue pia dalam ransum maka semakin rendah bobot badan yang dihasilkan. Hal ini memperlihatkan bahwa konsumsi ransum yang tinggi bukan berarti nilai gizi dalam tubuh ayam terpenuhi, sebaliknya konsumsi yang rendah tidak berarti nilai gizi yang dibutuhkan tidak terpenuhi. Hal ini dapat disebabkan dari kualitas ransum yang menurun dengan bertambahnya jumlah pemberian tepung limbah kue pia. Sesuai dengan pendapat North dan Bell (1990) yang menyatakan bahwa yang mempengaruhi kecepatan pertumbuhan pada unggas diantaranya yaitu kualitas dan kuantitas ransum.

Menurut Suarni dan Widowati (2007) komponen terbesar dalam biji jagung adalah karbohidrat berupa pati, sama halnya dengan tepung limbah kue pia yang terbuat dari tepung terigu yang sumber karbohidratnya berua pati. Namun diduga protein yang dikandung dari jagung dan tepung limbah kue pia berbeda kualitas jika dilihat dari kandungan asam amino esensialnya, sehingga kecepatan pertumbuhan yang dihasilkan berbeda. Hal ini karena pertumbuhan tidak hanya saja dipengaruhi oleh konsumsi ransum tetapi dari keseimbangan gizi ransum itu sendiri

\section{Pengaruh Perlakuan terhadap Konversi Ransum}

Konversi ransum merupakan perbandingan antara jumlah ransum yang dikonsumsi dengan pertambahan bobot badan selama pemeliharaan. Konversi ransum juga merupakan salah satu faktor yang menentukan keberhasilan dalam pemeliharaan ayam sentul, karena nilai konversi ransum menunjukan sejauhmana ransum yang dikonsumsi dapat dikonversikan menjadi daging.

Berdasarkan hasil penelitian pada tabel diatas, rataan konversi ransum paling rendah yaitu pada perlakuan $\mathrm{R} 1(2,91)$, diikuti berturut-turut pada perlakuan R3 $(2,91)$, R2 $(2,99), \quad$ R4 (3,02), dan R5 (3,20). Hasil perhitungan analisis ragam menunjukkan bahwa pengaruh perlakuan terhadap Konversi Ransum berbeda nyata, sehingga dilakukan uji lanjutan dengan menggunakan uji jarak berganda Duncan (UJBD) untuk mengetahui perbedaan antar perlakuan. Hasilnya menunjukkan bahwa perlakuan R1 tidak berbeda nyata dengan R3, R2 dan R4, tetapi berbeda nyata dengan R5, sedangkan R5 tidak berbeda nyata dengan R4 dan R2, tetapi berbeda nyata dengan R3 dan R1. 
Pemberian tepung limbah kue pia mempengaruhi konsumsi ransum dan pertumbahan bobot badan sehingga mempengaruhi juga nilai konversi ransum. Angka konversi ransum yang kecil berarti banyaknya ransum yang digunakan untuk menghasilkan satu kilogram daging semakin sedikit ( Kartasudjana dan Supriyatna, 2005). Nilai konversi ransum hasil penelitian menunjukan bahwa nilai konversi ransum meningkat seiring level pemberian tepung limbah kue pia. Hal ini akibat tingginya konsumsi ransum tidak di imbangi dengan pertambahan bobot badan yang tinggi sehingga efisiensi ransumnya menjadi tinggi. Sesuai dengan pernyataan Mulyono (2004) yang menyatakan angka konversi ransum yang tinggi menunjukkan penggunaan ransum yang kurang efisien, dan sebaliknya angka konversi ransum yang semakin kecil menunjukkan bahwa konsumsi ransumnya lebih efisien.

Lebih lanjut dijelaskan oleh Lacy dan Vest (2004) bahwa faktor utama yang mempengaruhi konversi ransum adalah genetik, kualitas ransum, penyakit, temperatur, sanitasi kandang, pengobatan dan managemen pemeliharaan. Faktor yang mempengaruhi konversi pakan adalah kecernaan pakan dan bentuk pakan (Lestari, 2013). Menurut Maryati (2000) Daya cerna pati tepung terigu adalah $97,41 \%$ sedangkan daya cerna pati jagung adalah 95,83\%. Hal ini menunjukkan bahwa limbah kue pia yang bahan utamanya terigu, memiliki daya cerna yang tinggi. Faktor yang mempengaruhi nilai konversi ransum pada penelitian ini diduga dari rendahnya kualitas ransum seiring dengan bertambahnya tepung limbah kue pia sehingga keseimbangan nutrisi yang terkandung di dalam ransum terutama asam amino menyebabkan nilai konversi menjadi tinggi.

\section{Kesimpulan}

disimpulkan bahwa :

Berdasarkan hasil penelitian dapat

1. Pemberian limbah kue pia sebagai pengganti jagung berpengaruh nyata terhadap performan ayam sentul.

2. Pemberian limbah kue pia sampai taraf $30 \%$ masih menghasilkan performa yang baik pada ayam sentul.

\section{Daftar Pustaka}

Anggorodi, R. (1985). Ilmu Makanan Ternak Unggas. Penerbit Universitas Indonesia. Jakarta

Anggorodi, R. (1995). Nutrisi Aneka Ternak Unggas. Penerbit PT. Gramedia Pustaka Utama. Jakarta.

Alfi, M. (2009). Pengaruh Penggunaan Tepung Roti Afkir Sebagai Pengganti Jagung dalam Ransum terhadap Produksi Karkas Ayam Broiler Jantan. Tesis. Universitas Diponegoro. Semarang

Gaol, S.E, Silionga L, dan Yuanita. (2015). Subtitusi Ransum Jadi dengan Roti Afkir terhadap Performa Burung Puyuh (Coturnix coturnix japocina) Umur Starter Sampai Awal Bertelur. Jurnal Ilmu Hewan Tropika. Vol 4 No. 2.

Indra Wahyu, Tanwiriah Wiwin, dan Widjastuti Tuti. (2015). Bobot potong, Karkas, dan income over feed cost Ayam Sentul Jantan pada Berbagai Umur Potong. Jurnal Unpad. Fakultas Peternakan, Universitas Padjadjaran. Vol 4, No 3.

Lestari, N. (2013). Pengaruh Penggunaan Fitobiotik sebagai Adiktif Pakan terhadap Penampilan Produksi Ayam Pedaging. Jurnal Fakultas Peternakan Universitas Brawijaya. Malang.

Kartasudjana, R dan E. Suprijatna. (2005). Manajemen Ternak Unggas. Penebar Swadaya. Jakarta

Kompiang I P., Supriyati, M.H. Togatorop dan S.N Jarmani. (2001). Kinerja Ayam Kampung dengan Sistem Pemberian Pakan Secara Memilih dengan Bebas. Jurnal Ilmu Ternak dan Veteriner Balai Penelitian Ternak. Bogor. Indonesia. Vol. 6 No. 2

Lacy M. P., dan L. R. Vest. (2004). Improving feed conversion in broiler : a guide for growers.

Maryati, S. (2000). Sistem Pencernaan Makanan. Erlangga. Jakarta.

Mulyono, S. (2004). Memelihara Ayam Buras Berorientasi Agribisnis. Penebar Swadaya, Jakarta

North, M.O and D.D. Bell. (1990). Commercial Chicken Production Manual. 4th Ed. The Avi Publishing Company Inc. Wesport Connecticut. New York. 
Suarni dan S. Widowati. (2007). Struktur, Komposisi, dan Nutrisi Jagung dalam Jagung. Pusat Penelitian Tanaman Pangan, Bogor. hlm. 410-426.

Sudrajat, Isyanto A.Y. (2018). Keragaan Peternakan Ayam Sentul di Kabupaten Ciamis. Jurnal Pemikiran Masyarakat Ilmiah Berwawasan Agribisnis. 4(2): 237-253.

Wahyu Juju. 2004. Ilmu Nutrisi Unggas. Cetakan ke-5.Gadjah Mada University Press. Yogyakarta
Widjiastuti dan Sujana. E.( 2009). Pemanfaatan Tepung Limbah Roti Dalam Ransum Ayam Broiler dan Implikasinya Terhadap Efisiensi Ransum Serta. Seminar Nasional Fakultas Peternakan Unpad Pengembangan Sistem Produksi dan Pemanfaatan Sumberdaya Lokal untuk Kemandirian Pangan Asal Hewan. Universitas Padjajaran. 